\title{
Environmental Management by Faith Based Organizations in Uganda: A SWOT Analysis
}

\author{
Patrick Mucunguzi ${ }^{1, ~ *}$, Patience Tugume ${ }^{1}$, Laster Ogola ${ }^{2}$ \\ ${ }^{1}$ Department of Plant Sciences, Microbiology \& Biotechnology, Makerere University, Kampala, Uganda \\ ${ }^{2}$ College of Education and Extra Mural, Makerere University, Kampala, Uganda
}

\section{Email address:}

patrick.mucunguzi@mak.ac.ug (P. Mucunguzi), patiebeys@gmail.com (P. Tugume), lastogola@gmail.com (L. Ogola)

${ }^{*}$ Corresponding author

\section{To cite this article:}

Patrick Mucunguzi, Patience Tugume, Laster Ogola. Environmental Management by Faith Based Organizations in Uganda: A SWOT Analysis. International Journal of Environmental Protection and Policy. Vol. 9, No. 1, 2021, pp. 5-15. doi: 10.11648/j.ijepp.20210901.12

Received: February 12, 2021; Accepted: March 9, 2021; Published: March 17, 2021

\begin{abstract}
Faith Based Organizations (FBOs) play a significant role in environmental management in Uganda. Despite this, they have been largely ignored in scholarship leading to a significant gap in understanding activities they carry out and challenges they encounter in environmental management. This study explored the strengths, weaknesses, opportunities and threats associated with environmental management by the FBOs in Uganda. FBOs selected and studied were the Roman Catholic Church, Anglican Church of Uganda, the Muslim Faith, Pentecostal Assemblies of God and the Seventh day Adventist, since they consist over $86 \%$ of Uganda's population. Qualitative and quantitative research strategies with systematic and purposive sampling techniques were used. SWOT analysis using Key Informant Interviews and questionnaires were carried out to obtain information from seven (7) key decision-making staff at the FBOs' headquarters and 75 from regional centers. Quantitative and qualitative data were analyzed by descriptive statistics and content analysis respectively. Key strengths of FBOs in environmental management include; land ownership, skilled human resources and finances. Existence of good structures from grassroots to national level, knowledge in environmental management and an extensive following countrywide boosts the capacity of FBOs to engage in environmental management activities. Major areas that need improvement are; knowledge and skills in environmental management of leaders and followers; resource mobilisation skills and interest in environmental conservation among most clergy and Imams. Key opportunities were; existence of large number of employees and followers who can be trained in environmental management and the structures from grass-root to national level. Key threats were human population explosion, poverty, land grabbing and unfavourable land tenure and policy changes. FBOs are instrumental in environmental management but are constrained by financial resources, limited knowledge and skills in environmental management and fundraising abilities. This calls for capacity building in these aspects in order to impart the required knowledge and skills to FBOs leaders and followers. Government and other able stakeholders should support FBOs in their endeavor to conduct environmental management activities in Uganda.
\end{abstract}

Keywords: Faith Based Organizations, Environmental Management, Stewardship

\section{Introduction}

Due to increasing environmental degradation resulting from human activities, there have been concerted efforts towards environmental management globally [1]. Environmental degradation has manifested itself in excessive natural resource extraction, biodiversity loss, habitat destruction, climate change, hunger, poverty, resource use conflicts, social and environmental injustice [2]. The
Sustainable Development Goals (SDGs), are a universal call to action to end poverty, protect the planet and ensure that all people enjoy peace and prosperity [3]. Uganda lost 781kha of tree cover accounting for $205 \mathrm{Mt}$ of $\mathrm{CO}_{2}$ emissions with the highest loss within the Lake Victoria basin between 2001 and 2018 [4]. Commodity-driven deforestation, high population of forest users and unsustainable utilization practices in the basin remain major threats to the forests. Building on these global efforts, Uganda as a country set out policies to demonstrate its commitment to their implementation. 
The recognition of the importance of Faith based organizations-FBOs in environmental conservation is recent and has been growing especially among the secular organizations [5-8]. Faith based organizations have a role to play in environmental conservation generally and for plant conservation in particular $[5,9]$. This is due to the following reasons; they are the largest organized sector of civil society worldwide; $84 \%$ of the world's 6.9 billion people described themselves as belonging to a faith by 2010 . For example, there were; 2.2 billion Christians, 1.6 billion Muslims, 1 billion Hindus, 0.5 billion Buddhists and 14 million Jews [10]. Additionally, FBOs own $7-8 \%$ of the habitable land surface of the planet including $5 \%$ of commercially run forests worldwide [7]. They are also involved in, or have influence over, around $15 \%$ of forests that are considered sacred and are founders of more than half of schools worldwide [11]. In some parts of the world, this figure is much higher. In parts of sub-Saharan Africa, faiths set up, run or contribute to about $70 \%$ of all schools and most importantly are trusted as a source of wisdom, information and authority in communities in many parts of the world [12]. Faith groups have been involved in their communities for the long-term [12]. Globally these faith based organizations own large tracts of land and financial resources important in environmental management activities such as tree planting [13-15]. FBOs think in terms of generations rather than in short-term projects, and are motivated by a sense of spiritual obligation or fulfillment. Faith groups bring about real, pragmatic changes and sustain actions and projects for the long-term. Faith based organizations are amongst the key organizations that influence views and practices of the people in various aspects such as peace building, conflict resolution or even conflict escalation, relief, health, recycling and environmental management [16-18, 7]. The challenge to all FBOs is to focus their operations on the basis of God's love and liberation being for all creation, and to seek new ways of living that restore balance and hope of life to the endangered planet [19]. The concept of stewardship has been applied in its most original and fundamental meaning to refer to our human responsibility to care for the Earth itself (Gen 1-2). Failure by humans as responsible stewards of earth has led to the current ecological crises threatening global climate stability, the ozone layer, and the diversity of plant and animal species [20]. The loss of forest and arable land in alarming proportions has tremendous implications for food security [21].

Tree planting and forest conservation are highly advocated for mitigation actions against climate change [8]. Globally, tree planting has received attention from various stakeholders at local, national and international levels. In addition, faith based organizations have greatly and historically played an important role in conserving natural resources, protection of forests and trees [22-24]. Malaysia Islamic principles offer great teaching on environmentalism through recycling [25]. In the year 2009, representatives from various religions worldwide confirmed their commitment to address climate change through increasing forest cover [26]. Environment
Management Policy for Uganda (2014) emphasized the crucial role Faith Based Organizations play through advocacy, mobilization and dialogue with communities [27]. The Uganda national NGOs Policy recognized the contribution of Faith Based Institutions in environmental management within the development activities [28]. The network of faith based partners in environmental education formed in 2014 in East Africa included the Catholics, Anglicans, Muslims, Pentecostals, Seventh Day Adventists, the Bahai and Hindus and secular organizations like Alliance of Religions on Conservation (ARC) [11].

The Church of Uganda Provincial Master Strategic Plan 2016 - 2025 identified effective environmental management as one of the key areas of focus [29]. According to the national census of 2014, Uganda has many FBOs belonging to different denominations in the following proportions: Catholics 39.3\%, Anglicans 32.0\%, Moslems 13.7\%, Pentecostal/Born Again/Evangelicals $11.1 \%$ and Seventh Day Adventists $1.7 \%$ of the total Uganda's population of $34,634,650$. Others include the Baptist $(0.3 \%)$, Orthodox $(0.1 \%)$ and the traditionalists $(0.1 \%)$. All religious affiliations whose percentage to the total population is less than 0.1 were categorisedunder others and they include the Salvation Army, Baha'i, Jehovah's Witness, Presbyterian, Hindus, Mammon, Jews and Buddhists [30].

Despite the significant role that FBOs play in environmental management, there is scanty information regarding their current involvement [8, 31]. This study examined the extent to which faith based organizations have integrated environmental management in their policies and activities. It also identified the benefits and challenges of FBOs involvement in environmental management that are less documented and analysed in Uganda to give an effective way forward. Effective involvement in environmental management by FBOs can enhance the country's capacity in restoring the degraded environment in Uganda while contributing to achieving national, regional and global development priorities especially the Sustainable Development Goals (SDGs). Therefore, understanding the role of faith based organizations in environmental management in Uganda is crucial in determining the extent of their involvement in that sector. Specifically, the study identified the strengths, weaknesses, opportunities and threats of the FBOs in environmental management in Uganda. The study further examined the main environmental activities FBOs are engaged in, their benefits and challenges met.

\section{Methodology}

\subsection{Research Design}

The study was both qualitative and quantitative in nature. The scope of the faith based organizations in this study was limited to; Roman Catholic Church, Anglican Church of Uganda, Muslim Faith, Pentecostal Assemblies of God and the Seventh day Adventist. These organizations were chosen because they have a following of over $86 \%$ of Uganda's 
population [32]. The study was first conducted at the headquarters for the selected FBOs and then at their regional centers in Northern, Eastern, Southern, Western and Central Uganda. A preliminary discussion was carried out at places of leadership in all identified faith based organizations before the detailed study was done. The aim of the discussion was to seek for permission, provide information on the study to be done and to select potential centers and employees for further investigations.

\subsection{Sample Selection}

Purposive sampling was used to select a total of seven respondents from all FBOs headquarters [33]. These comprised of one senior staff from; Uganda Catholic Secretariat- Caritas, Household and Community Transformation Directorate (Anglican), Directorate for Social Services in the Uganda Muslim Supreme Council, the Superintendent, Kibuli Grand Mosque, Directorates of Women Ministries and Education Uganda Union, and Health /HIV/AIDS for the Seventh day Adventist and the Directorate for Social Development Services, Pentecostal Assemblies of God. At the regional centers, houses of worships such as churches and mosques were selected systematically (Table 1).

Table 1. Study areas of different faith based organisations.

\begin{tabular}{|c|c|c|c|c|c|}
\hline \multirow{2}{*}{$\begin{array}{l}\text { Faith Based } \\
\text { Organization }\end{array}$} & \multicolumn{5}{|l|}{ Region in Uganda where study was conducted } \\
\hline & Central & Western & Southern & Eastern & Northern \\
\hline Roman Catholic & $\begin{array}{l}\text { Caritas Headquarters, Masaka, Kasana- } \\
\text { Luweero Dioceses }\end{array}$ & Kasese Diocese & $\begin{array}{l}\text { Mbarara, Kigezi } \\
\text { Dioceses }\end{array}$ & $\begin{array}{l}\text { Soroti, Jinja } \\
\text { Dioceses }\end{array}$ & $\begin{array}{l}\text { Arua, Gulu \& } \\
\text { Lira Dioceses }\end{array}$ \\
\hline $\begin{array}{l}\text { Anglican Church of } \\
\text { Uganda }\end{array}$ & $\begin{array}{l}\text { Directorate of Household and Community } \\
\text { transformation [Kampala Headquarters] } \\
\text {-Masaka \& Luweero Districts }\end{array}$ & $\begin{array}{l}\text { Kasese \& } \\
\text { HoimaDistricts }\end{array}$ & $\begin{array}{l}\text { Mbarara \& } \\
\text { Kigezi Districts }\end{array}$ & $\begin{array}{l}\text { Soroti \& Jinja } \\
\text { Districts }\end{array}$ & $\begin{array}{l}\text { Arua, Gulu and } \\
\text { Lira Districts }\end{array}$ \\
\hline Seventh Day Adventist & $\begin{array}{l}\text { Seventh Day Adventist Headquarters } \\
\text {-Masaka\&Kampala Pastorates }\end{array}$ & $\begin{array}{l}\text { Kasese \& Hoima } \\
\text { Pastorates }\end{array}$ & Kigezi Pastorate & $\begin{array}{l}\text { Soroti, Mbale \& } \\
\text { Jinja Pastorate }\end{array}$ & $\begin{array}{l}\text { Arua \& Apac } \\
\text { Pastorate }\end{array}$ \\
\hline
\end{tabular}

Data were collected by conducting in-depth semistructured face-to-face interviews with key informants (nonprobability sample). These were individuals who are especially knowledgeable about the specific faith management policies, plans and activities [8, 34]. Data from other respondents were collected through a questionnaire survey. Key informants at regional centres included; senior administrators mostly Financial Officers, administrators, Agricultural Officers, Bishops, Clergies, Councilors, Curate, Diocesan Education Coordinators, Diocesan Planning and Development Officers, Diocesan Secretaries, Muslim District Secretaries, Executive Directors, Land Officers, Evangelists, Departmental managers, Mothers Union Development Coordinator, Priests, Pastors, Programmes officers, Project officers, managers, Secretary for social services, and teachers The primary objective of interviews was to gain a better understanding of the key engagements, benefits and challenges met by FBOs in environmental management for the entire leadership and members across faith based organizations in Uganda. This was a paper based interview guide and recording of respondents' answers from semistructured interviews was done by the note-taker present during the interview [35].

The interview protocol included basically six open-ended questions put forward to all 75 respondents (Catholic 20, Anglican 22, Muslim 16, Seventh day Adventist 7, Pentecostal Assemblies of God 8 and Orthodox 2) all purposively selected. The questions focused on the major themes of the study: estimated number of Parishes and parishioners, the presence of an environmental management policy and its means of dissemination to local communities /parishioners, key resources for environmental management, current/planned environmental management activities a, benefits and current and anticipated challenges encountered while managing the environment.

The subjects of discussion during interviews followed a three-part topical order [8]. The first part focused on introducing the research team, purpose of the interview and its benefits. The second part focused on examining the knowledge and perceptions of participants about faiths' role in environmental management. The final part focused on key resources that enable the faith to engage in environmental management, current and anticipated challenges. All interviews were conducted in English. The interview protocol was carefully verified and validated by analysis of the questionnaire survey information. The respondents' information was tested for its representativeness, reliability and validity. Content analysis and descriptive statistics were used to present data from interviews for common themes across open-ended questions.

\subsection{Data Collected}

Regarding environmental management, key areas investigated included; presence of an environmental management policy and how it is communicated; voluntary environmental programs participated in; and proportion of employees that have attended environmental trainings.

Regarding Strengths the questionnaires sought answers for; environmental practices done, possession of unique knowledge, talents, or resources for both the FBOs and their parishioners; and the greatest achievement (s) of FBOs in environmental management.

For Weaknesses the questionnaires sought for responses towards aspects or areas that need improvement by the FBO; knowledge, talents, skills and/or resources lacking in the FBO; what other people say FBO does/or do not do well; areas in which the FBO require more training; and Parishioners' complaints about FBO's role in environmental 
management.

For Opportunities the questionnaire sought answers on how FBO can turn strength into opportunities; how FBOs can turn weaknesses into opportunities; what the FBO could presently do that is not being done; changes taking place in the FBOs and how they can take advantage of the changes; and how FBOs could support parishioners to engage in environmental management.

For Threats; the questionnaire sought for; obstacles faced by FBO; whether any of the identified weaknesses prevent the FBO from meeting its goals; who or what might cause FBOs problems in future regarding environmental management? Presence of any standards, policies and/or legislation that might negatively impact the FBO; and whether there are changes in the FBO's field or in technology that could threaten their success in environmental management?

Data from questionnaires were coded and entered into Statistical Package for Social Sciences (SPSS) version 16 software. Quantitative data was presented using descriptive statistics such as frequencies and graphs. Qualitative data obtained from Key Informant interviews were analyzed using opinion and content analysis to draw important themes emerging from interviews.

\section{Results}

\subsection{Units and Congregations of the Main FBOs in Uganda}

The Roman Catholic FBO in Uganda has 4 Ecclesiastical Provinces with a total of 15 suffragan Dioceses with about 13.4 million people. The Anglican FBO has one Archdiocese with 37 Dioceses with about 11.0 million people. The Muslim based faith has nine regions with 65 Districts and a congregation of about 4 million people. The Seventh Day Adventist FBO has 6 Fields/Conferences equivalent to Dioceses with a congregation of about 600,000 . The Pentecostal Assemblies of God has about 111 churches in Uganda with over 7000 congregations.

\subsection{Presence and Communication of the Environmental Policy and Environmental Management System}

A majority of the respondents (54\%) indicated absence of an environmental policy in the FBO except for the Anglican Church of Uganda. However, the Pentecostal Assemblies of God had a draft policy that was not yet operationalized. The Roman Catholic Church indicated presence of environmental policy in the central and southern regions. The Anglican Church of Uganda and the Muslim Faith had Environmental Management System arrangements for implementation of
Environmental policies which were not yet verified. Only $24 \%$ of FBOs communicated the environmental policy to their congregations during service/mass/juma prayer sermons on worship days.

A summary of methods of environmental policy communication is illustrated in figure 1 .

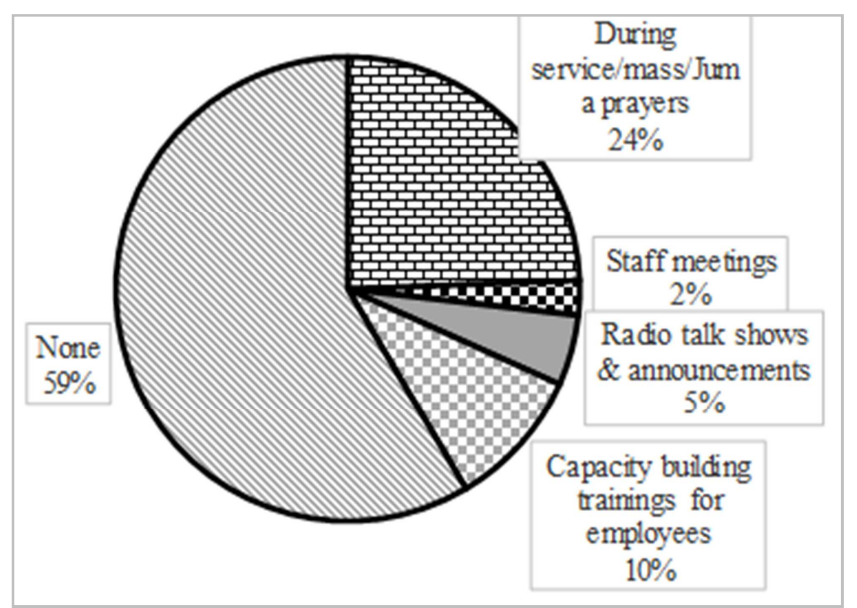

Figure 1. Percentage (\%) of environmental policy communication methods at selected FBOs in Uganda.

\subsection{Environmental Audits and Participation in Environmental Trainings}

Regarding the question on whether internal and external audits are performed at the FBO facilities, only the Muslim Faith that constituted $9.8 \%$ of the FBOs investigated indicated that they conduct both internal and external environmental audits, while $87.8 \%$ representing the other FBOs do not and $2.4 \%$ were indifferent. The proportion of employees that had attended environmental management trainings was $48.8 \%$ who were mainly staff of the Pentecostal Assemblies of God, Anglican Roman Catholic faiths and some Muslims in the central, eastern and Kabale (Southern) regions only. Other faiths had few employees that had attended.

\subsection{Key Natural Resources Owned by FBOs}

The key resources owned by all FBOs and their congregations were land and human resources (Table 2). The key resources owned by FBOs that facilitate environmental management activities are land, human resources, finances, offices and vehicles (Table 2). The Roman Catholic and Anglican faiths possessed all the five resources while the Muslim, Seventh Day Adventist and Pentecostal Assemblies of God lacked finances, offices and vehicles.

Table 2. Key natural resources owned by FBOs in Uganda.

\begin{tabular}{lllll}
\hline Key Resource Category & \multicolumn{4}{l}{ Number and percentage of FBOs with resource materials for environmental management } \\
\hline Resource materials & Roman Catholic/n=11 & Anglican C. O. U/n=12 & Muslim Faith/n=8 & SDA/n=5 \\
\hline Land & $10(90.9 \%)$ & $12(100 \%)$ & $6(75 \%)$ & $2(40 \%)$ \\
Human & $11(100 \%)$ & $11(91.6 \%)$ & $6(75 \%)$ & $3(60 \%)$ \\
Finances & $6(54.5 \%)$ & $2(17) \%$ & $0 \%$ & $4(50 \%)$ \\
Offices & $10(90.0 \%)$ & $2(17 \%)$ & $0 \%$ & $0 \%$ \\
Vehicles & $10(90.0 \%)$ & $2(17 \%)$ & $0 \%$ & $0 \%$ \\
\hline
\end{tabular}


The Anglican Church of Uganda had only land and human resource in northern and eastern Uganda but lacked offices, vehicles and finances to promote environmental management activities. In southern and western Uganda, Kabale, Mbarara, Kasese possessed land and human resourcesbut these were limited at Hoima. Kabale and Mbarara Dioceses had offices, vehicles and finances to promote environmental management activities, but these were limited at Kasese and Hoima.

\subsection{SWOT Analysis of Faith Based Organizations in Environmental Management}

\subsubsection{Strengths}

These refer to characteristics of a FBO that givesit an advantage over other organizations in environmental management. All FBOs reported possession of three areas of strength viz: good structures from grassroots to national level, members knowledgeable in environment management and a wide following countrywide (Table 3). The Muslimand the
Seventh day Adventist organizations reported usage of Quran and bible verses in sensitizing their members on environmental management. Key Bible verses were: Genesis 1:4-12; Genesis 1:26-30; Genesis 2:8-9; Genesis 2:15; Genesis 8:22; 15:22-25; Exodus 23:10-11; Leviticus 25:24, 26:32-35; Deuteronomy 6:11; Deuteronomy 23:12-13; Numbers 4:6; Leviticus 19:23, 25:1-7; Psalms 115:16; Proverbs 13:22a; Ecclesiastes 2:5; Ecclesiastes 3:26; Ecclesiastes 11:6; Isaiah 6; Isaiah 16:5; Isaiah 24:4-6; Isaiah 44:14, 41:19-20; Luke 13:6-9; 1 Corinthians 9:6 and Galatians 6:7. The key Quaran verses were: Chapter nuru verse 34; Kuran-Surat Abasa, verse 24-32; Surah 2:60 and Surah 57:10.

The Roman Catholic and the Anglican organizations reported having respectable church leaders whose advices are easily followed by their flocks. A summary of other characteristics that confer advantage to the different FBOs are summarized in Table 3.

Table 3. Strengths of the FBOs in environmental management in Uganda.

\begin{tabular}{ll}
\hline FBO & Unique knowledge, talent, or resources of FBOs \\
\hline \multirow{3}{*}{ Catholic } & 1. Advocacy \\
& 2. Good mobilization strategies \\
& 3. Good structures from grassroots to national Level \\
& 4. Respected leaders of the church \\
5. Vast experience in environmental conservation \\
1. Skilled personnel in environmental protection and community sensitization on Environmental management \\
2. Good structures from grassroots to national level \\
3. Respected leaders of the church \\
1. Quran has scriptures on Environmental Conservation \\
2. There are some Muslims knowledgeable in environmental management \\
3uslim & 4. Wide following countrywide \\
& 1. Bible based scriptures for environmental protection \\
Seventh Day Adventist & 2. Good structures from grassroots to national level \\
& 3. Numerous loyal followers from countrywide \\
1. Competent personnel in environmental management & 2. Climate change adaptation best practices \\
Pentecostal Assemblies of God & 3. Wide followers from over 5000 churches countrywide \\
& 4. Good structures from grassroots to national level \\
\hline
\end{tabular}

\subsubsection{Weaknesses}

These are the characteristics that place the FBO or its members at a disadvantage relative to others in environmental management. The major weaknesses reported include; limited capability by FBOs to conduct environmental conservation activities or to establish an environmental policy/management system (25\%) lack of knowledge on woodlot/nursery bed establishment and management $(23 \%)$ and limited sensitization of members to engage in environmental conservation (26.2\%). Other weaknesses identified were; lack of capacity to carry out timely tree planting, lack of knowledge regarding the tree species required for propagation, financial and land constraints.

All FBOs indicated the need to improve in the following three key areas; knowledge and skills of FBOs leaders and followers in environmental management; resource mobilisation especially fundraising skills and low interest in environmental conservation among most clergy and Imams (Table 4). Other unique issues are demarcating and titling land for the Anglican Church and environmental policy development for the Pentecostal assemblies of God and the Seventh-day Adventist organizations. Environmental entrepreneurship was identified by the Roman Catholic as lacking in their FBO. Another aspect identified for improvement was the insufficient effort to promote environmental protection at community level especially by women and children. The seventh day Adventist highlighted lack of training in project planning as a limiting factor to implementation of environmental management activities. 
Table 4. Aspects or areas that need improvement by FBOs for environmental management.

\begin{tabular}{|c|c|}
\hline FBO & Aspects/areas that need improvement \\
\hline \multirow{9}{*}{ Catholic } & 1. Coordinating Diocesan efforts more effectively \\
\hline & 2. Promotion of Climate Smart Agriculture \\
\hline & 3. Knowledge on intricacies of climate change \\
\hline & 4. Environmental entrepreneurship \\
\hline & 5. Mobilization of children for environmental protection \\
\hline & 6. Increase the interest of clergy in environmental protection \\
\hline & 7. Utilization of most of the church land for environmental conservation \\
\hline & 8. Promotion of environmental protection at community level \\
\hline & 9. Promotion of Agroforestry for wealth creation \\
\hline \multirow{7}{*}{ Protestant } & 1. Demarcating and titling land owned by the church \\
\hline & 2. More research on environment management \\
\hline & 3. Knowledge on formulating environmental policies \\
\hline & 4. Knowledge on fundraising skills and strategies \\
\hline & 5. Knowledge on oil and gas and extracting other minerals \\
\hline & 6. Involve more of the women and youth in its church operations \\
\hline & 7. More training in capacity building of church leaders on climate change mitigation and adaptation practices \\
\hline \multirow{6}{*}{ Muslim } & 1. Interest in environmental conservation among most Imams and other Muslim leaders \\
\hline & 2. Knowledge and skills on Environmental management to all Imams and other Muslim leaders \\
\hline & 3. Resource mobilization e.g. financial support for environmental management \\
\hline & 4. Practical implementation of environmental programs \\
\hline & 5. Increase sensitization of Muslim followers \\
\hline & 6. Training Muslim followers in environmental management and conservation \\
\hline \multirow{10}{*}{ Seventh Day Adventist } & 1. Development of environmental policies and their enforcement \\
\hline & 2. Sensitization on environmental conservation \\
\hline & 3. Increase the Technical personnel \\
\hline & 4. Interest in environmental conservation among church leadership \\
\hline & 5. Establish an office/department for environmental conservation \\
\hline & 6. More church involvement in community programs \\
\hline & 7. Monitoring of planted trees \\
\hline & 8. More training in Environmental management \\
\hline & 9. Skills in Project planning \\
\hline & 10. Skills in Resource mobilization \\
\hline \multirow{5}{*}{ Pentecostal } & 1. Specific policies and their enforcement \\
\hline & 2. More competent technical personnel \\
\hline & 3. Funds to implement mandates \\
\hline & 4. More training in Climate change resilience \\
\hline & 5. Natural resource governance and management \\
\hline
\end{tabular}

Table 5. Practices FBOs can do to turn strengths, weaknesses and changes into opportunities.

\begin{tabular}{|c|c|}
\hline FBO & Practices to turn strength into opportunities \\
\hline \multirow{2}{*}{ Catholic } & 1. Leaders must be sensitized about environmental protection \\
\hline & 2. Mobilization of the Christian communities during project implementations \\
\hline \multirow{5}{*}{ Protestant } & 1. Use the land for tree planting \\
\hline & 2. Training the available human resource to build their capacity \\
\hline & 3. Use the structure of the church from grass roots to national level to disseminate environment management information \\
\hline & 4. Collaborating with government for joint implementation of environmental management projects \\
\hline & $\begin{array}{l}\text { 5. Change in FBOs approach from emphasizing spiritual aspects only preaching holistically by incorporating spiritual issues } \\
\text { alongside social development }\end{array}$ \\
\hline \multirow{4}{*}{ Muslim } & 1. The huge numbers of Muslims can be used to protect environment \\
\hline & 2. The different structures be used to propagate the information on environmentmanagement \\
\hline & 3. The Quran can be used as a basic guide for environmental conservation \\
\hline & 4. Take advantage of the existing different technical people in the various offices for environmental management \\
\hline & 1. Use the church land for tree planting \\
\hline Seventh Day & 2. Use prime radio to disseminate environment management information \\
\hline \multirow{3}{*}{ Adventist } & 3. Training church leaders and followers on environmental protection \\
\hline & 4. Take advantages of new change where FBOs have started working together \\
\hline & 1. To use the 5000 churches and thousands of followers to cause holistic transformation in communities \\
\hline \multirow[t]{2}{*}{ Pentecostal } & 2. Build capacity of more employees to promote environmental conservation \\
\hline & 3. Take advantage of government regulations on FBOs as an opportunity to provetheir relevance in environmental management. \\
\hline
\end{tabular}

\subsubsection{Opportunities}

These are the elements that FBOs could exploit to their advantage in environmental management. The three most important elements that FBOs can exploit to enhance tree planting are; the existence of large number of employees and followers for involvement in environmental management training and the presence of structures from grass-root to 
national level (Table 5). The Muslim faith further pointed out the use of the Quran verses as a basic guide to environmental conservation while the SDA pointed out the use of media in the sensitization of the community. Additionally, increased networking among FBOs has potential to enhance their concerted efforts in environmental management. The Anglican organizations own vast acres of land which could be utilised for tree planting. They also recognize the need of change in approach from only spiritual emphasis to a combined approach of spiritual, social and economic values resulting from, integrated environmental benefits.

\subsubsection{Threats}

These are the elements in the environment that could threaten the activities of FBOs in environmental management. The key elements identified that are likely to impede tree planting by FBOs are; human population explosion and poverty that could lead to land scarcity, unfavourable land tenure systems, policy changes and land grabbing (Table 6). Shortage of financial and human resources could negatively impact on the capacity of FBOs to carry out tree planting projects.

Table 6. Obstacles likely to be faced by FBOs in future tree planting activities.

\begin{tabular}{|c|c|}
\hline FBO & Obstacle to future tree planting by FBOs \\
\hline Catholic & $\begin{array}{l}\text { 1. Human population explosion and poverty could lead to land scarcity } \\
\text { 2. Limited support from clergy } \\
\text { 3. Limited financial resources }\end{array}$ \\
\hline Protestant & $\begin{array}{l}\text { 1. Land grabbing might lead to deforestation and loss of church land } \\
\text { 2. Production and Operation Management POMA } \\
\text { 3. Land Act } \\
\text { 4. NGO registration Act }\end{array}$ \\
\hline Muslim & $\begin{array}{l}\text { 1. Shortage of resources to carry out environmental projects } \\
\text { 2. Ignorance regarding the value of the environment may hinder people from carrying out environmental management activities. } \\
\text { 1. Environmental conservation is not a priority of the church }\end{array}$ \\
\hline Seventh Day & 2. Land tenure and Policy issues \\
\hline Adventist & 3. Government security issues \\
\hline & 4. Bureaucracy in registration and licensing of FBOs \\
\hline Pentecostal & $\begin{array}{l}\text { 1. Environmental conservation is not a priority of the church } \\
\text { 2. Limited access to adequate land for tree planting } \\
\text { 3. Unfavorable government policies and development plans } \\
\text { 4. Poor enforcement of government and church policies }\end{array}$ \\
\hline
\end{tabular}

\subsection{Ways FBOs Can Support Parishioners/Followers in Tree Planting}

Three key strategies FBOs could use to support parishioners' involvement in tree planting/natural forest management in their environments were identified as; training leaders to use the land they own for tree planting; provision of tree seedlings for propagation to FBOs followers and sensitization of the congregations about benefits of tree planting and its implications in climate change mitigation (Table 7). The Seventh day Adventist faith mentioned establishment of demonstration centers to be valuable in the promotion of tree planting by followers.

Table 7. Ways FBOs can support parishioners in tree planting.

\begin{tabular}{ll}
\hline FBO & Ways FBO can support parishioners in tree planting/natural forest management in their areas \\
\hline \multirow{3}{*}{ Catholic } & 1. - Train leaders in tree planting and provide them with tree seedlings \\
& 2. -Providing followers with trust funds \\
3. - Creating environmental committees at Parish and community levels \\
Protestant & 1. - Train leaders in tree planting \\
Muslim & 2. -Provide followers with tree seedlings \\
& Train the leaders on using owned land for tree planting \\
1. Train leaders in tree planting & 2. Provide followers with tree seedlings \\
& 3. Establishment of forest demonstration centres \\
& 1. Use available church land to plant more trees by parishioners \\
Pentecostal & 2. Incorporate tree planting in some of the sermons \\
& 3. Sensitize congregations on climate change adaptation and mitigation strategies.
\end{tabular}

\section{Discussion}

\subsection{Key Resources Owned by FBOs}

The key resources owned by all FBOs and their followers relevant to environmental management were land and human resources. Daily and Huang (2001) identified human resource (HR) factors as key elements in the implementation of an Environmental Management System. A study by Zubair and Garforth, 2006 in Pakistan indicated that tree growing decisions were significantly influenced by availability of barren land [36]. Land ownership, land size and previous experience in the forestry were positively correlated to the 
intention to plant trees for timber [37]. The Roman Catholic and the Seventh Day Adventist organizations also had finances to facilitate environmental management activities such as tree planting. Presence of permanent land is very vital in tree planting, agriculture and infrastructural development. Human resources are important in conducting sensitization activities after training and can participate in environmental management activities mainly on their own land.

\subsection{Strengths of FBOs in Environmental Management}

The existence of good structures from grassroots to national level, presence of knowledgeable members in environmental management and a wide following countrywide confer an advantage to all FBOs in implementing environmental management activities especially tree planting. The Muslim and the Seventh day Adventist organizations reported usage of Quran and bible verses respectively in sensitizing their members about environmental management. The use of biblical or Quran verses in mobilizing for environmental conservation has been cited in other studies [38, 39]. Such verses promote environmental action through engaging followers in debates concerning "dominion" or "stewardship" of God's creation. The emphasis on creation care suggests a reinterpretation of the "dominion doctrine" found in Genesis 1:26-28. Several religious actors make clear that the doctrine is not about dominion to wreck or destroy, but to respect and protect. However, some churches in the United States still consider "dominion" as license to exploit [40]. Durrant described Christian obligations to God's creation as "important to enrich people's spiritual relationship with God, and to motivate their righteous behaviour towards the earth [41]. However, other studies reported a negative relationship between biblical literalism and environmental concern [42-44].

According to Islam, humans are part of the holistic system of life created by God, and although humans have the right to survive, they have been given the role of responsible leadership on earth [45]. A study by Rice in Egypt found an association between Islamic religious teachings and proenvironmental behavior [46].

The Roman Catholic and the Anglican churches reported having respectable church leaders as an added advantage to them when it came to promoting environmental management activities. This is so important in an African setting where religious leaders are respected members of the society, and can be trusted by donors with their funds to implement different environmental management projects. Churches and faith-based agencies play a key role in effecting sustainable and holistic change due to their rootedness in the community, the social capital they produce, and the respect received from the people.

\subsection{Areas for Improvement by FBOs in Environmental Management}

The participation of FBOs in tree planting activities was limited by knowledge and skills in environmental management of FBO sleaders and their followers; poor resource mobilization skills and low interest in environmental conservation among most clergy and Imams. Demarcating and titling of land for the Anglican and environmental policy development for the Pentecostal Assemblies of God and the Seventh-day Adventist required urgent attention in order to promote environmental conservation activities. Possession of formal land titles positively influenced adoption of soil conservation strategies in Vietnam. Therefore, the issuance of land titles is a necessary prerequisite of encouraging FBOs to adopt environmental conservation practices. Land titling improves the ability of landholders to legally exclude competing users and thereby strengthens incentives to manage forests or trees thereon for long-term benefits [47].

Environmental entrepreneurship was identified by the Roman Catholic Church as lacking in their organization. Yet some scholars have argued that entrepreneurial action can address the problem of degradation of the natural environment [48, 49]. It is therefore important that environmental entrepreneurship is promoted in all FBOs for their successful engagement in environmental conservation activities.

Another aspect identified for improvement was the insufficient effort to promote environmental protection at community level especially by women and children. The seventh day Adventist further required training in project planning. Increased knowledge and skills in environmental management among the leaders and followers of FBOs, will enhance their understanding and implementation of practices of environmental management and tree planting. Improved skills in fundraising and proposal writing will enhance the FBOs capacity to mobilize financial resources for tree planting on their land, as well as acquisition of more land.

\subsection{Opportunities Available to FBOs in Environmental Management}

All FBOs identified the large number of employees and followers and the presence of a structure from grass-root to national level as opportunities they could exploit to enhance environmental management especially tree planting. The elaborate structure amidst large number of followers is important for transmission of information and skills regarding tree planting. The Muslim faith further pointed out the use of the Quran verses as a basic guide to environmental conservation. The use of Quran and bible verses are important in reminding and mobilizing followers who believe and trust in God and are willing to fulfill his instructions for environmental stewardship. The first value promoted by the holy books is that of love, awe and respect for God's creation which is sometimes referred to as creation care or stewardship [50, 51]. Viewing the Earth as part of God's creation, and the belief that humans are to take care of it can prove to be a big motivator for followers' in different faiths to engage in activities that protect the environment.

The SDA noted that the use of media in the sensitization of the community and increased networking among FBOs can 
enhance their concerted efforts in environmental management. A study by Okaka and Apilin 2013 conducted in Uganda identified an urgent need to mainstream the Information Communications Technologies in environmental policy awareness communication strategy [52]. The same study indicated that electronic media was the most accessible channel in delivering environmental policy messages countrywide. The increasing availability and capacity to acquire multi-media in Uganda will greatly enhance information and training capacity of the FBOs in mobilizing their followers, as well as networking within and between other FBOs and Government institutions. The Anglican identified land they have for tree planting and the change in the approach from only spiritual emphasis to a combined approach of spiritual, social and economic, is important for integrating environmental concerns also.

\subsection{Threats of FBOs in Environmental Management}

The key threats likely to impede tree planting by the FBOs were identified as; human population explosion and poverty that could lead to land scarcity, unfavourable land tenure and policy changes and land grabbing issues. One way of responding to human population increase is to encourage tree planting as agro-forestry on limited land. Titling land, maintenance of clear boundaries and utilizing free land for tree planting will limit land grabbing and thus loss of land. Shortage of resources to carry out environmental management projectscould negatively impact on tree planting by the FBOs.

\subsection{FBOs Support Towards Environmental Management}

FBOs need to support their parishioners in conducting environmental management activities especially tree planting/natural forest management through; training their leaders on how to utilize the land owned for tree planting; provision of tree seedlings and sensitization regarding tree planting and climate change. Through these efforts FBOs followers will be mobilized to engage in tree planting on their private land resulting into increase in tree cover. The Seventh day Adventist faith identified establishment of demonstration centres by FBOs as a factor that promotes tree planting by followers. These demonstration centres facilitate transfer knowledge and skills to other leaders and followers in tree nursery establishment in addition to being role models to their communities.

\section{Conclusions}

The key resources owned by key faith based organizations in Uganda were land and human resources. The Roman Catholic and the Seventh Day Adventist also identified finances as major boost that facilitates environmental management activities particularly tree planting. The dominant strengths in all FBOs were; existence of good structures from grassroots to national level, knowledgeable members in environmental management and a wide following countrywide. However, some areas that need improvement were noted to include; the knowledge and skills in environmental management for FBOs leaders and followers; resource mobilization skills and low interest in environmental conservation among most clergy and Imams. The opportunities that FBOs can tap to enhance their involvement in environmental management included; existence of large number of employees and followers who could undertake environmental management training, and the presence of a structures from grass-root to national level. The threats to environmental management activities identified were; human population explosion and poverty that could lead to land scarcity, unfavourable land tenure, policy changes and land grabbing. FBOs have more opportunities than challenges for in implementing environmental management activities in Uganda. The existing challenges can be overcome when leaders and their followers are sensitized adequately. Therefore, Faith based organizations have a role to play in the conservation of the environment but are constrained by mindsets and financial resources.

Even if FBOs are not currently a leading force behind national environmental policies in Uganda, it is clear that they have a large potential for shaping new attitudes to nature given the huge following. The rich religious traditions of the different FBOs that relate humans to nature will promote greater involvement in environmental management issues.

The study recommends that in order to enhance the role of FBOs in the environmental management and tree planting there is need for enhanced collaborative efforts between the FBOs, environmental organisations and government especially in provision of funds and training to carry out environmental management activities.

\section{Acknowledgements}

This study was part of a bigger REDD+ project Uganda with a research registered number with Uganda National Council for Science and Technology NS 511. Special thanks go to leaders, staff and followers of FBOs that provided us with the required data for this study.

\section{References}

[1] United Nations Research Institute for Social Development (1994). Environmental Degradation and Social Integration. UNRISD Briefing Paper No. 3 World Summit for Social Development.

[2] Owusu-Koranteng, D. (2010). The Role of the Church in promoting environmental stewardship, Feature Article of Sunday, $\quad 18 \quad$ April 2010 http://www.ghanaweb.com/GhanaHomePage/features/TheRole-of-the-Church-in-promoting-environmental-stewardship180344.

[3] UNDP (2015). Sustainable Development Goals Booklet. Retrieved

fromhttps://www.undp.org/content/undp/en/home/librarypage/ corporate/sustainable-development-goals-booklet.html. 
[4] Curtis, P. Slay, M. C., Harris, N. L., and Tyukavina, A. \& Hansen, M. (2018). Classifying drivers of global forest loss. Science. 361. 1108-1111. 10.1126/science.aau3445.

[5] Cox, M., Villamayor-Tomas, S. and Hartberg, Y. (2014). The Role of Religion in Community-based Natural Resource Management. World Development, 54, 46-55. https://doi.org/10.1016/j.worlddev.2013.07.010.

[6] Kristen Lyons, Peter Walters \& Erin Riddell (2015). The Role of Faith-based Organizations in Environmental Governance: the Case of Forestry in Solomon Islands. Journal of Environmental Policy \& Planning. DOI: 10.1080/1523908X.2015.1098524.

[7] United Nations Environment Programme (2020). Faith Action on the UN Sustainable Development Goals: Progress and Outlook. URI: http://hdl.handle.net/20.500.11822/33848.

[8] Nche, G. C. (2020). Beyond Spiritual Focus: Climate Change Awareness, Role Perception, and Action among Church Leaders in Nigeria. American Meteorological Society. DOI: 10.1175/WCAS-D-19-0001.1.

[9] Orlowska, I. \&Klepeis, P. (2018) Ethiopian church forests: a socioreligious conservation model under change. Journal of Eastern African Studies, 12: 4, 674-695. DOI: 10.1080/17531055.2018.1519659.

[10] The Pew Research Center- Religion \& Public Life (2012). The Global Religious Landscape https://www.pewforum.org/2012/12/18/global-religiouslandscape-exec/.

[11] USAID (2014). The faith based environmental education stakeholders' workshop report. $24^{\text {th }}$ and $25^{\text {th }}$ March, 2014, publication produced by the Jane Goodall Institute and The Alliance of Religions and Conservation on behalf of ABCG.

[12] Heist, D. \&Cnaan, R. A. (2016). Faith-Based International Development Work: A Review. Religions2016, 7, 19; the Special Issue Religion, Welfare and Social Service Provision: Common Ground. https://doi.org/10.3390/rel7030019.

[13] Deressa, T., T., Hassan, R., M., Ringler, C., Alemu, T. \& Yesuf, M. (2009). Determinants of farmers' choice of adaptation methods to climate change in the Nile Basin of Ethiopia. Global Environmental Change. https://doi.org/10.1016/j.gloenvcha.2009.01.002.

[14] Ndayambaje, J. D., Heijman, W. J. M., \& Mohren, G. M. J. (2012). Household Determinants of Tree Planting on Farms in Rural Rwanda. Small-Scale Forestry. https://doi.org/10.1007/s11842-012-9196-0.

[15] United Nations Environmental Programme (2018). Engaging with faith-based organizations. UN Environment Strategy. https://wedocs.unep.org/bitstream/handle/20.500.11822/25989 $/$ UNEP\%20Strategy\%20Engaging\%20FBOs.pdf?sequence $=1$ \&isAllowed $=\mathrm{y}$. Accessed 20 Jan 2021.

[16] Silberman, I., Higgins, E. T., \& Dweck, C. S. (2005). Religion and world change: Violence and terrorism versus peace. Journal of Social Issues. https://doi.org/10.1111/j.15404560.2005.00431.x.

[17] Karyotis, G. \& Patrikios, S. (2010). Religion, securitization and anti-immigration attitudes: The case of greece. Journal of Peace Research. https://doi.org/10.1177/0022343309350021.

[18] Seneviratne, H. L. (2011). Religion and Conflict. In Faith-
Based Diplomacy Trumping Realpolitik. https://doi.org/10.1093/acprof:oso/9780195367935.003.0004.

[19] Palmer, M. \& Finlay, V. (2003). Faith in Conservation: New Approaches to Religions and the Environment. World bank Publications, ISBN 0821355597, 9780821355596, 166 pages.

[20] Rhoads, D. (2019). Stewardship of Creation, the Web of Creation https://www.webofcreation.org/archive-ofresources/505-stewardship-of-creation accessed 02 Jan 2019.

[21] Sunderland, T., Powell, B., Ickowitz, A., Foli, S., PinedoVasquez, M., Nasi, R. and Padoch, C. (2013). Food security and nutrition: The role of forests. Discussion Paper. CIFOR, Bogor, Indonesia.

[22] Liao, C., Luo, Y., Fang, C. \& Li, B. (2010). Ecosystem Carbon Stock Influenced by Plantation Practice: Implications for Planting Forests as a Measure of Climate change mitigation. PLoS ONE. https://doi.org/10.1371/journal.pone.0010867.

[23] Paquette, A. \& Messier, C. (2010). The role of plantations in managing the world's forests in the Anthropocene. Frontiers in Ecology and the Environment. https://doi.org/10.1890/080116.

[24] Yachkaschi, A., \& Yachkaschi, S. (2012). Nature conservation and religion. An excursion into the Zoroastrian religion and its historical benefits for the protection of forests, animals and natural resources. Forest Policy and Economics. https://doi.org/10.1016/j.forpol.2011.12.002.

[25] Mohamad, Z. F., Idris, N., Baharuddin, A., Muhammad, A., \& Nik Sulaiman, N. M. (2012). The role of religious community in recycling: Empirical insights from Malaysia. Resources, Conservation and Recycling, 58, 143-151. https://doi.org/10.1016/j.resconrec.2011.09.020.

[26] Mangunjaya, F.\& McKay, E. (2012). Reviving an islamic approach for environmental conservation in indonesia. Worldviews: Environment, Culture, Religion, 16, 286-305. https://doi.org/10.1163/15685357-01603006.

[27] The National Environment Management Policy for Uganda, 2014.

[28] Bakiika, R. (2013). An overview of non-state actors in environment and natural resources management in Uganda. A working paper from the Environment and Natural resources CSO Network (ENR CSO Network) contribution to the review of the national environment management policy for Uganda.

[29] The Church of Uganda, Provincial Master Strategic Plan 2016 -2025 , Vision 2025.

[30] Uganda Bureau of Statistics (2016). The National Population and Housing Census 2014 - Main Report, Kampala, Uganda.

[31] Moyer, J. M., Sinclair, A. J. \&Spaling, H. (2012). 'Working for God and Sustainability: The Activities of Faith-Based Organizations in Kenya', Voluntas23.4: 959-92. Doi: http://dx.doi.org/10.1007/s11266-011-9245-x.

[32] Uganda Bureau of Statistics (2014). National Population and Housing Census. Kampala, Uganda.

[33] Dworkin, S. L. (2012). Sample Size Policy for Qualitative Studies Using In-Depth Interviews. Archives of Sexual Behavior Volume 41, Issue 6, pp 1319-1320. 
[34] Krishna, K. (1989). Conducting key informant interviews in developing countries, Center for Development Information and Evaluation, Agency for International Development Program Design and Evaluation Methodology Report No. 13.

[35] Kabir, Syed Muhammad. (2016). Basic guidelines for research: An Introductory Approach for All Disciplines.

[36] Zubair, M., \&Garforth, C. (2006). Farm level tree planting in Pakistan: the role of farmers' perceptions and attitudes. Agroforestry Systems 66: 217-229.

[37] Emtage, N., \& Suh, J. (2004). Socio-economic factors affecting smallholder tree planting and management intentions in Leyte Province, Philippines. Small-scale Forest Economics. Management and Policy, 3 (2), 257-270.

[38] DeLashmutt, M. W. (2011)."Church and Climate Change: an Examination of the Attitudes and Practices of Cornish Anglican Churches Regarding the Environment."Journal for the Study of Religion, Nature and Culture, 5 (1): 61-81.

[39] Kearns, L. (2011). The Role of Religions in Activism."InThe Oxford Handbook of Climate Change and Society, edited by JohnDryzek, Richard B. Norgaard, and David Schlosberg, 414-428. Oxford: Oxford University Press.

[40] Acton Institute. (2000). The Cornwall declaration on environmental stewardship. Accessed March 5, 2017. http://www.acton.org/public-policy/environmentalstewardship/cornwall-declaration.

[41] Durrant, K. (2014). The Earth Will Teach you. London: Wide Margin Books.

[42] Eckberg, D. L., \& Blocker, T. J. (1996). Christianity, environmentalism, and the theoretical problem of fundamentalism. Journal for the Scientific Study of Religion, $35,343-355$.

[43] Guth, J. L., Green, J. C., Kellstedt, L., \& Smidt, C. (1995). Faith and the environment: Religious beliefs and attitudes on environmental policy. American Journal of Political Science, $39,64-382$.

[44] Schultz, P. W., Unipan, J. B., \& Gamba, R. J. (2000). Acculturation and ecological worldview among Latino Americans. Journal of Environmental Education, 31 (2), 22 27.

[45] Izzi Dien, M. (2003). Islam and the environment: Theory and practice. In R. C. Foltz, F. M. Denny, \& A. Baharuddin (Eds.), Islam and ecology (pp. 107-20). Cambridge, MA: Harvard University Press.

[46] Rice, G. (2006). Pro-environmental behavior in Egypt: Is there a role for Islamic environmental ethics? Journal of Business Ethics, 65, 373-390.

[47] Buntaine, M. T., Hamilton, S. E., \&Millones, M. (2015). Titling community land to prevent deforestation: An evaluation of a best-case program in Morona-Santiago, Ecuador. Global Environmental Change, 33, 32-43.

[48] Muñoz, P. and Dimov, D. (2015). 'The call of the whole in understanding the development of sustain-able ventures'. Journal of Business Venturing, 30, 632-54.

[49] Patzelt, H. and Shepherd, D. A. (2011). 'Recognizing opportunities for sustainable development'. Entrepreneurship Theory and Practice, 35, 631-52.

[50] Kearns, L. (1996). "Saving the Creation: Christian Environmentalism in the United States." Sociology of Religion 57 (1): 55-70. doi: 10.2307/3712004.

[51] DeWitt, C. (1998). Caring for Creation: Responsible Stewardship of God's Handwork. Grand Rapids, MI: Baker Books.

[52] Okaka, W., \&Apil, J. (2013). Innovative ICT public awareness campaign strategy to communicate environmental sustainability in Africa. In 2013 IST-Africa Conference \& Exhibition (pp. 1-9). IEEE. 